\title{
Orlistatand and Rosuvastatin Suppressed Proliferation of K562 Human Myelogenous Leukemia Cell Line through AMPK/Akt/c-Myc Signaling
}

\section{Behnam Mojjarad}

Department of Biology, Faculty of Science, Urmia University, Urmia, Iran

Yaghub Pazhang ( $\sim$ y.pazhang@urmia.ac.ir)

Department of Biology, Faculty of Science, Urmia University, Urmia, Iran

Primary research

Keywords: Chronic Myeloid Leukemia, K562, Orlistat, Rosuvastatin, Apoptosis

Posted Date: April 10th, 2020

DOI: https://doi.org/10.21203/rs.3.rs-18877/v2

License: (c) (1) This work is licensed under a Creative Commons Attribution 4.0 International License. Read Full License 
The authors have withdrawn this preprint from Research Square 